\title{
Air Quality Assessment in the Vicinity of Quarry Site
}

\author{
Babatunde Saheed Bada ${ }^{1}$, Kofoworola Amudat Olatunde ${ }^{1}$ \& Oluwafunmilayo Abidemi AKande ${ }^{1}$ \\ ${ }^{1}$ Department of Environmental Management and Toxicology, Federal University of Agriculture, Abeokuta, Ogun \\ State, Nigeria \\ Correspondence: Babatunde Saheed Bada, Department of Environmental Management and Toxicology, Federal \\ University of Agriculture, Abeokuta, Ogun State, Nigeria. Tel: 234-803-725-0964. E-mail: \\ bsbada2000@yahoo.com
}

Received: August 23, 2012 Accepted: March 15, 2013 Online Published: March 21, 2013

doi:10.5539/enrr.v3n2p111

URL: http://dx.doi.org/10.5539/enrr.v3n2p111

\begin{abstract}
This study investigated air pollutants associated with quarry activities and the variation of the pollutants with distance from the drilling section. Air pollutants were monitored with the use of automatic air samplers with the exception of ozone $\left(\mathrm{O}_{3}\right)$ which was determined by iodometric method. All sampling were replicated three times. The data obtained were subjected to descriptive statistics, analysis of variance and correlation. Means were separated using Duncan Multiple Range test. Carbon monoxide and carbon dioxide were detected while sulphur dioxide, nitrogen oxide and $\mathrm{O}_{3}$ were below detection limit. Suspended particulates were the most significant of the air pollutants analyzed. Crushing section had the highest concentrations of $\mathrm{PM}_{10}$ and $\mathrm{PM}_{2.5}$ with $0.231 \pm$ $0.018 \mathrm{mg} / \mathrm{m}^{3}$ and $0.130 \pm 0.010 \mathrm{mg} / \mathrm{m}^{3}$ respectively followed by the drilling section with $0.074 \pm 0.066 \mathrm{mg} / \mathrm{m}^{3}$ for PM10 and $0.065 \pm 0.045 \mathrm{mg} / \mathrm{m} 3$ for $\mathrm{PM}_{2.5}$. The mean levels of the total suspended particulate decreased significantly $(\mathrm{p}<0.05)$ with distance from the crushing section to Jagun village.
\end{abstract}

Keyeord: air, quality, quarry site

\section{Introduction}

The process of getting useful stone from a quarry is known as quarrying. The methods and equipment used in quarry depend on the purpose for which the stone is extracted. Different quarrying activities have different impacts on air quality (Alaturca, 2012). The process of making holes in rock, limestone or overburden with the aid of a drilling machine (drilling process) may be treated as a point source of pollutant emission. Shattering the drilled limestone or overburden in a bid to loosen the mass in smaller fragments (blasting process) may be treated as an instantaneous point source for suspended particulate. Also, the loading and movement of dumper trucks on haul routes would generate suspended particulates while the crushing of ore and transferring it to a belt conveyor (ore processing) would be a potential source of dust generation. Loading and movement of vehicles may be treated as point and line sources. Mineral exploration, mining and processing have resulted in environmental damages including ecological disturbance, destruction of natural flora, pollution of air, land and water, instability of soil and rock masses, landscape degradation and radiation hazards (Aigbedion \& Iyayi, 2007) . Dust is the main source of air pollution in quarry industry. The extent of pollution by dust depends on the local microclimate conditions, the concentration of dust particles in the ambient air, the size of the dust particles and their chemistry (Hsin-Yi, 2012). Dust has effect both on human health and the natural environment. It can lead to chronic health effects for instance decreased lung capacity and lung cancer resulting from long-term exposure to toxic air pollutants (Sunyer, 2001). However, it blocks and damages the internal structure and abrasion of leaves and cuticles (Hsin-Yi, 2012). The number of quarrying industries in Ogun State, Nigeria is kept on increasing. Although it contributes to the internally generated revenue, there is need to look at its effect on the neigbouring communities and the environment in general. Work has been done on the levels of heavy metals in soil and vegetation of a quarry site (Bada \& Fagbayibgo, 2009) and on the level of suspended particulates in the ambient air and around selected quarry sites (Oguntoke et al., 2009) but much work has not been done on the effect of quarry activities in relation to the emission of greenhouse gases and suspended particulates. The objectives of this study were to identify the various air pollutants associated with quarry activities and determine the variation in the concentration of the pollutants with respect to the distance from the drilling section. 


\section{Materials and Methods}

\subsection{Location of the Company}

This study was carried out in the vicinity of a quarry company, FW SAN HE CONCEPTS LIMITED, along Abeokuta-Ibadan road, Odeda Local Government Area, Ogun State, Nigeria. Figure 1 shows the location of the company in Odeda Local Government Area, Ogun State, Nigeria. The quarry company engages in the production of granite for sale to construction companies and registered agents. The climate of Abeokuta follows a tropical pattern with the rainy season lasting for between seven and eight months between April and October with an interruption in August and the dry season running through November till February. The maximum temperature, minimum temperature, total rainfall, relative humidity, sunshine, wind speed and evaporation for the month of December, 2010 (sampling month) were $31.9{ }^{\circ} \mathrm{C}, 22.4^{\circ} \mathrm{C}, 0.00 \mathrm{~mm}, 81.1 \%, 7.2$ hours, $0.09 \mathrm{~km} / \mathrm{hr}(2.05 \mathrm{~km} /$ day) and $3.0 \mathrm{~mm}$ respectively (FUNAAB, Meteorological Station, 2010).

\subsection{Sample Collection and Analysis}

Ambient air samples were taken in the major activities areas of the quarry such as the drilling point, crushing section, loading section, generator house, workshop, administrative section and Jagun village (Table 1). Active sampler was used for all the parameter except ground level ozone where iodometric method was used (Table 2). Active sampling makes use of pump to pull air through filter while iodometric method involves titration. Average time for sampling was 1 hour for active sampler and 72 hours for iodometric method. Sampling was carried out in the afternoon and replicated times.

The parameters measured in the sampled air were sulphur dioxide $\left(\mathrm{SO}_{2}\right)$, oxides of nitrogen $\left(\mathrm{NO}_{\mathrm{X}}\right)$, carbon monoxide $(\mathrm{CO})$, carbon dioxide $\left(\mathrm{CO}_{2}\right)$ and ground level ozone $\left(\mathrm{O}_{3}\right)$. Total Suspended Particulates (TSP), respirable and inhalable particulates $\left(\mathrm{PM}_{2.5}\right.$ and $\left.\mathrm{PM}_{10}\right)$ were also measured.

\subsection{Statistical Analysis}

The data obtained were subjected to descriptive statistics, analysis of variance and correlation. The significance of the treatment means were determined using Duncan Multiple Range (DMR) test.

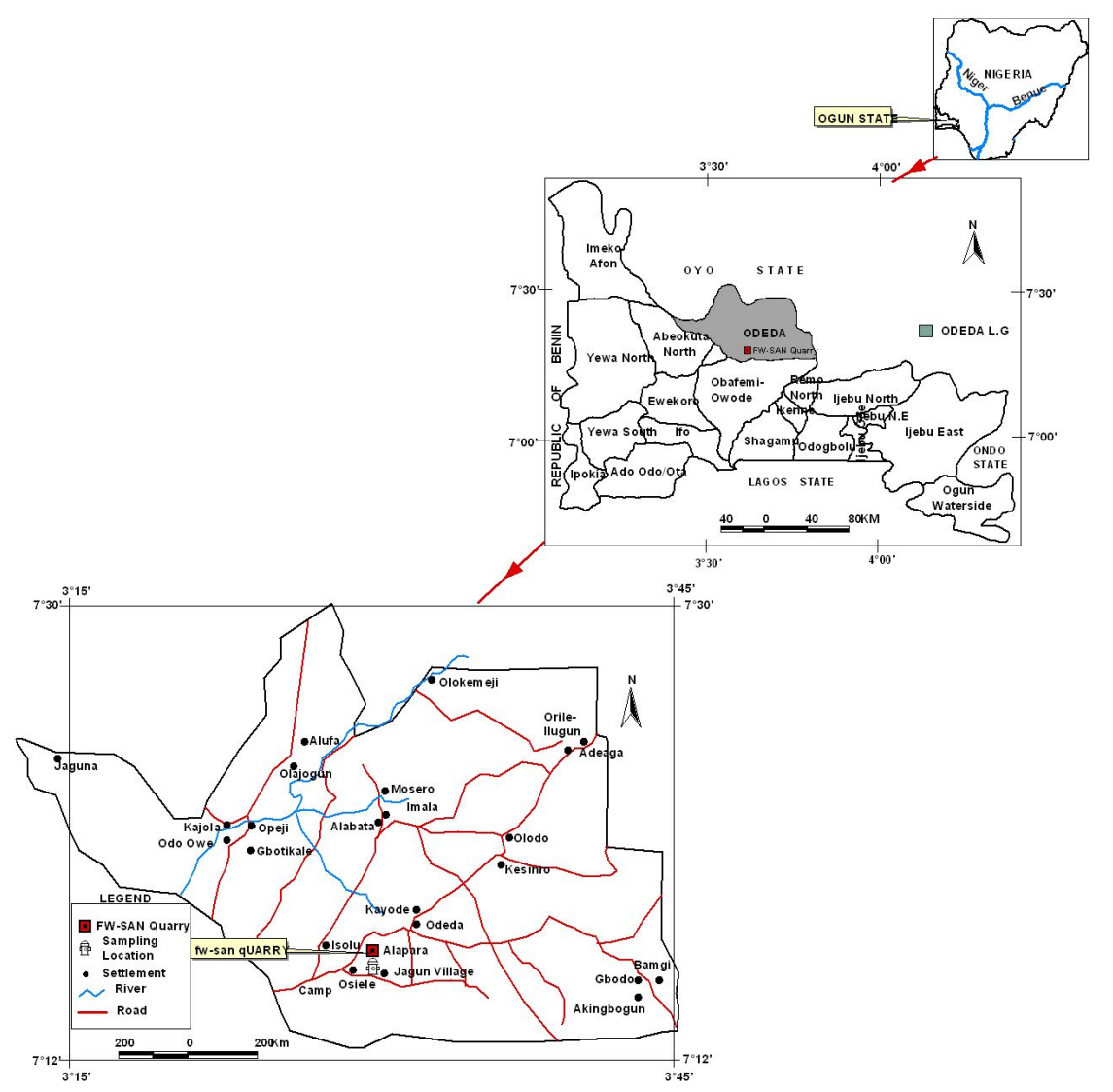

Figure1. Location of the company in Odeda Local Government Area, Ogun State, Nigeria 
Table 1. Distance and coordinates of sampling locations with respect to the drilling point

\begin{tabular}{llll}
\hline Location & Distance $(\mathrm{m})$ & Latitude & Longitude \\
\hline Drilling point & 0 & $\mathrm{~N} 07^{\circ} 14^{\prime} 54.3^{\prime \prime}$ & $\mathrm{E} 003^{\circ} 29^{\prime} 38.4^{\prime \prime}$ \\
Crushing Section & 500 & $\mathrm{~N} 07^{\circ} 14^{\prime} 51.8^{\prime \prime}$ & $\mathrm{E} 003^{\circ} 29^{\prime} 36.0^{\prime \prime}$ \\
Loading Section & 700 & $\mathrm{~N} 07^{\circ} 14^{\prime} 50.0^{\prime \prime}$ & $\mathrm{E} 003^{\circ} 29^{\prime} 36.4^{\prime \prime}$ \\
Generator House & 900 & $\mathrm{~N} 07^{\circ} 14^{\prime} 48.1^{\prime \prime}$ & $\mathrm{E} 003^{\circ} 29^{\prime} 35.6^{\prime \prime}$ \\
Workshop & 1000 & $\mathrm{~N}^{\circ} 17^{\circ} 14^{\prime} 52.0^{\prime \prime}$ & $\mathrm{E} 003^{\circ} 29^{\prime} 35.0^{\prime \prime}$ \\
Admin. Section & 1300 & $\mathrm{~N} 07^{\circ} 14^{\prime} 50.1^{\prime \prime}$ & $\mathrm{E} 003^{\circ} 29^{\prime} 34.8^{\prime \prime}$ \\
Jagun village & 5000 & $\mathrm{~N} 07^{\circ} 13^{\prime} 47.4^{\prime \prime}$ & $\mathrm{E} 003^{\circ} 29^{\prime} 17.5^{\prime \prime}$ \\
\hline
\end{tabular}

Table 2. Air parameters analyzed and instruments used

\begin{tabular}{ll}
\hline Parameter & Instrument \\
\hline $\mathrm{SO}_{2}$ & Gas Alert analyzer \\
$\mathrm{CO}, \mathrm{CO}_{2}, \mathrm{NO}_{\mathrm{X}}$ & Land Duo flue gas analyzer \\
$\mathrm{PM}_{2.5}$ & PDR-1200 Airborne particulate monitor \\
$\mathrm{PM}_{10}$ & TSI Piezobalance respirable Aerosol Mass Monitor \\
$\mathrm{TSP}$ & PPM 1005 Handheld Aerosol Monitor \\
Ground level ozone & Iodometric method \\
\hline
\end{tabular}

\section{Results}

Sulphur dioxide $\left(\mathrm{SO}_{2}\right)$, oxides of nitrogen $\left(\mathrm{NO}_{\mathrm{X}}\right)$ and ozone $\left(\mathrm{O}_{3}\right)$ concentrations in the ambient air were below detection limit (Table 3). Concentration of carbon monoxide (CO) was highest in the drilling point followed by the crushing section, loading section and workshop place. Generator house had the least concentration of CO. Significantly $(\mathrm{p}<0.05)$ higher carbon dioxide $\left(\mathrm{CO}_{2}\right)$ was observed at the village and drilling section with mean values of $1.74 \pm 0.45 \%$ and $1.38 \pm 0.50 \%$ respectively.

Significantly $(\mathrm{p}<0.05)$ higher $\mathrm{PM}_{10}$ was observed at the crushing and loading sections (Table 4). The least significant $(\mathrm{p}<0.05)$ values of $\mathrm{PM}_{10}$ were observed at administrative section and Jagun village. For $\mathrm{PM}_{2.5}$, significantly $(\mathrm{p}<0.05)$ higher concentration was observed at the crushing section followed by the drilling section and loading section. Total suspended particulates decreased with distance from the crushing section (Table 4).

There was significant $(\mathrm{p}<0.05)$ positive correlation between carbon monoxide $(\mathrm{CO})$ and particulate matter $\left(\mathrm{PM}_{2.5}\right.$ and $\left.\mathrm{PM}_{10}\right)($ Table 5).

\section{Discussion}

The levels of carbon dioxide $\left(\mathrm{CO}_{2}\right)$ in the village and drilling point were significantly $(\mathrm{p}<0.05)$ higher than other locations. The high level experienced at the village might be due to the use of fire wood for cooking and the proximity of the sampling points to the main road in the village. Bada and Akande (2010) stated that vehicular emission contribute to the concentration of $\mathrm{CO}_{2}$ in the atmosphere. Carbon monoxide (CO) concentration was significantly $(\mathrm{p}<0.05)$ higher at the drilling point and crushing section. This might be due to the incomplete combustion of fuel by heavy duty machineries used in the drilling and crushing activities of quarrying. However, the values were below the Standard of 9 ppm (USEPA, 1996). However, sulphur dioxide $\left(\mathrm{SO}_{2}\right)$, oxides of nitrogen $\left(\mathrm{NO}_{\mathrm{X}}\right)$ and Ozone $\left(\mathrm{O}_{3}\right)$ in the ambient air of the sampling sites were below detection limit. Chaulya (2005) stated that emission of $\mathrm{SO}_{2}$ and $\mathrm{NO}_{\mathrm{X}}$ are negligible. This is also in agreement with the prediction of the United State Environmental Protection Agency (USEPA) that 
Table 3. Mean levels of gaseous pollutants in the vicinity of quarry site

\begin{tabular}{lllllll}
\hline Sampling location & Distance $(\mathrm{m})$ & $\mathrm{CO}(\mathrm{ppm})$ & $\mathrm{CO}_{2}(\%)$ & $\mathrm{SO}_{2}(\mathrm{ppm})$ & $\mathrm{NO}_{\mathrm{X}}(\mathrm{ppm})$ & $\mathrm{O}_{3}(\mathrm{ppm})$ \\
\hline Drilling section & 0 & $6.00 \pm 0.00^{\mathrm{a}}$ & $1.38 \pm 0.50^{\mathrm{a}}$ & $<0.01$ & $<0.01$ & $<0.01$ \\
Crushing section & 500 & $5.50 \pm 0.50^{\mathrm{a}}$ & $<0.01$ & $<0.01$ & $<0.01$ & $<0.01$ \\
Loading section & 700 & $2.00 \pm 1.00^{\mathrm{b}}$ & $0.15 \pm 0.15^{\mathrm{c}}$ & $<0.01$ & $<0.01$ & $<0.01$ \\
Generator house & 900 & $1.50 \pm 0.50^{\mathrm{b}}$ & $0.95 \pm 0.35^{\mathrm{b}}$ & $<0.01$ & $<0.01$ & $<0.01$ \\
Workshop & 1000 & $2.00 \pm 1.00^{\mathrm{b}}$ & $0.65 \pm 0.30^{\mathrm{bc}}$ & $<0.01$ & $<0.01$ & $<0.01$ \\
Administration section & 1300 & $<1.00$ & $0.91 \pm 0.62^{\mathrm{b}}$ & $<0.01$ & $<0.01$ & $<0.01$ \\
Jagun village & 5000 & $<1.00$ & $1.74 \pm 0.45^{\mathrm{a}}$ & $<0.01$ & $<0.01$ & $<0.01$ \\
\hline
\end{tabular}

1.00 - detection limit for $\mathrm{CO}$.

0.01 - detection limit for $\mathrm{CO}_{2}, \mathrm{SO}_{2}, \mathrm{NO}_{\mathrm{x}}$ and $\mathrm{O}_{3}$.

Values are means \pm standard deviation of three replicates.

Different superscript in the same column indicate significant differences at $\mathrm{p}<0.05$ according to Duncan Multiple Range Test (DMRT).

Table 4. Mean levels of particulate matters $\left(\mathrm{mg} / \mathrm{m}^{3}\right)$ in the vicinity of quarry site

\begin{tabular}{lllll}
\hline Sampling location & Distance $(\mathrm{m})$ & $\mathrm{PM}_{10}$ & $\mathrm{PM}_{2.5}$ & $\mathrm{TSP}$ \\
\hline Drilling section & 0 & $0.074 \pm 0.066^{\mathrm{b}}$ & $0.065 \pm 0.045^{\mathrm{b}}$ & $0.629 \pm 0.072^{\mathrm{b}}$ \\
Crushing section & 500 & $0.231 \pm 0.018^{\mathrm{a}}$ & $0.130 \pm 0.010^{\mathrm{a}}$ & $3.545 \pm 1.365^{\mathrm{a}}$ \\
Loading section & 700 & $0.078 \pm 0.024^{\mathrm{a}}$ & $0.050 \pm 0.020^{\mathrm{b}}$ & $0.618 \pm 0.052^{\mathrm{b}}$ \\
Generator house & 900 & $0.049 \pm 0.004^{\mathrm{b}}$ & $0.040 \pm 0.040^{\mathrm{b}}$ & $0.550 \pm 0.004^{\mathrm{b}}$ \\
Workshop & 1000 & $0.052 \pm 0.012^{\mathrm{b}}$ & $<0.01$ & $0.559 \pm 0.013^{\mathrm{b}}$ \\
Administration section & 1300 & $0.033 \pm 0.023^{\mathrm{b}}$ & $<0.01$ & $0.547 \pm 0.003^{\mathrm{b}}$ \\
Jagun village & 5000 & $0.030 \pm 0.021^{\mathrm{b}}$ & $<0.01$ & $0.498 \pm 0.058^{\mathrm{b}}$ \\
\hline
\end{tabular}

0.01- detection limit for $\mathrm{PM}_{2.5}$.

Values are means \pm standard deviation of three replicates.

Different superscript in the same column indicate significant differences at $\mathrm{p}<0.05$ according to Duncan Multiple Range Test (DMRT).

Table 5. Correlation coefficient of air pollutants

\begin{tabular}{llllll}
\hline Variables & $\mathrm{CO}$ & $\mathrm{CO}_{2}$ & $\mathrm{PM}_{2.5}$ & $\mathrm{PM}_{10}$ & $\mathrm{TSP}$ \\
\hline $\mathrm{CO}$ & 1.00 & & & & \\
$\mathrm{CO}_{2}$ & 0.138 & 1.00 & & & \\
$\mathrm{SPM}_{2.5}$ & $0.711^{*}$ & -0.404 & 1.00 & & \\
$\mathrm{SPM}_{10}$ & $0.742^{*}$ & -0.446 & $0.861^{* *}$ & 1.00 & \\
$\mathrm{TSP}$ & -0.328 & -0.500 & -0.227 & 0.194 & 1.00 \\
\hline
\end{tabular}

* significant at 0.05 probability level.

** significant at 0.01 probability level.

suspended particulate matter is quite outstanding among the pollutants emanating from quarry operations (USEPA, 2008).

Mean levels of $\mathrm{PM}_{10}$ at both the drilling and the crushing sections were higher than the permissible level of 50 $\mu \mathrm{g} / \mathrm{m}^{3}$ (WHO, 2005). However, $\mathrm{PM}_{2.5}$ concentration at the crushing and drilling section were higher than the 
permissible limit of $35 \mu \mathrm{g} / \mathrm{m}^{3}$ (USEPA, 1996) and $25 \mu \mathrm{g} / \mathrm{m}^{3}$ (WHO, 2005). These particles may therefore lodge in human lungs, thereby causing lung damages and respiratory problems (Last, 1998). The mean values of Total Suspended Particulates (TSP) in all the sampling locations were higher than the permissible level of $230 \mu \mathrm{g} / \mathrm{m}^{3}$ (World Bank, 1998). Particulate matter in the air are transported from the point of generation to areas far removed (UNEP, 1991).

Significant $(\mathrm{p}<0.05)$ positive correlation was observed between carbon monoxide $(\mathrm{CO})$ and particulate matter $\left(\mathrm{PM}_{2.5}\right.$ and $\left.\mathrm{PM}_{10}\right)$. This might be an indication that the pollutants were emitted from the same source. $\mathrm{PM}_{2.5}$ and $\mathrm{PM}_{10}$ showed significant $(\mathrm{p}<0.01)$ positive correlation. These pollutants were associated and released from the same source (USEPA, 2008).

\section{Conclusion}

Quarry activities released air pollutants into the environment. Air pollutants such as Total Suspended Particulates (TSP), particulate matter $\left(\mathrm{PM}_{2.5}\right.$ and $\left.\mathrm{PM}_{10}\right)$ and greenhouse gases like $\mathrm{CO}$ and $\mathrm{CO}_{2}$ were detected while $\mathrm{SO}_{2}$, $\mathrm{NO}_{\mathrm{x}}$ and ozone were below the detection limit. Highest levels of $\mathrm{PM}_{2.5}, \mathrm{PM}_{10}$ and TSP were generated at the crushing section.

For sustainable quarry activities, quarry site should be located in the interior surrounded by adequate vegetation which would act as sinks and block for various emissions emanating from the quarry. Inhabitant of the area where a quarry is to be sited should be relocated to prevent the impact of the emissions generated by the quarry industries on them.

\section{References}

Aigbedion, I., \& Iyayi, S. E. (2007). Environmental effect of mineral exploitation in Nigeria. International Journal of Physical Sciences, 2(2), 33-38.

Bada, B. S., \& Akande, E. A. (2010). Greenhouse gases concentrations in the atmosphere along selected roads in Abeokuta, Ogun State, Nigeria. Ethiopian Journal of Environmental Studies and Management, 3(1), 78-82. http://dx.doi.org/10.4314/ejesm.v3i1.54404

Bada, B. S., \& Fagbayigbo, B. O. (2009). Heavy metal levels of soil and vegetation in vicinity of a quarry site. In A. S. Fasina, O. J. Ayodele, A. E. Salami \& S.O. Ojeniyi (Eds.), Proceedings $33^{\text {rd }}$ Annual Conference of Soil Science Society of Nigeria. (pp. 280-284). Published by Interlink.

Chaulya, S. K. (2005). Air quality status of an open pit mining area in India. Environmental Monitoring and Assessment, 105, 369-389. http://dx.doi.org/10.1007/s10661-005-4345-y

FUNAAB (Federal University of Agriculture, Abeokuta) Meteorological Station. (2010). Means of Agrometeorological Observation, prepared by the Department of Agrometeorology and Water Management, p. 1.

Hsin-Yi, C. (2012). The impact of quarrying. Retrieved December 14, 2012, from www.sustainablefloors.co.uk

Last, J. M. (1998). Public health and human ecology (2nd ed.). (pp. 153-200). Prentice-Hall International Canada: McGraw-Hill Medical Publishing.

Oguntoke, O., Aboaba, A., \& Gbadebo, T. A. (2009). Impact of granite quarrying on the health of workers and nearby residents in Abeokuta, Ogun State, Nigeria. Ethiopian Journal of Environmental Studies and Management, 2(1), 1-11.

Sunyer, J. (2001). Urban air pollution and chronic obstructive pulmonary disease: a review. European Respiratory Journal, 17(5), 1024-1033. http://dx.doi.org/10.1183/09031936.01.17510240

UNEP (United Nations Environment Programme). (1991). Urban air pollution. In: Environment Library, No 4, Nairobi, Kenya.

USEPA (United State Environmental Protection Agency). (1996). Review of National ambient air quality standards for particulate matter: Policy assessment of scientific and technician information, report no. EPA452/R-96-013 (USEPA, Washington DC) pp v-20, v-24, v-27, v-28 and v-71.

USEPA (United State Environmental Protection Agency). (2008). Region 4: Laboratory and field operations$\mathrm{PM}_{2.5}$ Objectives and history. Retrieved February 3, 2010, from en.wikipedia.org/wiki/particulate

WHO (World Health Organization). (2005). Air quality guidelines global update. Report on a working group meeting, Bonn, Germany, 18-20 October, 2005.

World Bank. (1998). Pollution prevention and abatement handbook, pp. 275-278. 